\title{
Raza y clase en los orígenes del peronismo: Argentina, 1945
}

\author{
ALEJANDRO GRIMSON
}

En el marco de los debates sobre identificaciones raciales y de clase, este artículo analiza dos términos clave utilizados para designar de manera peyorativa a los seguidores de Perón: descamisados y cabecitas negras. La movilización del 17 de octubre de 1945 fue la mayor protesta obrera hasta ese entonces en Sudamérica. Abrió un debate sobre quiénes eran sus protagonistas y los antiperonistas los identificaron en términos de clase y de raza. Las reacciones del peronismo ante esos términos fueron muy distintas: para "descamisados", Perón generó una inversión de sentido, mientras que se hizo silencio en referencia a "cabecitas negras". Este ensayo busca contribuir a comprender cómo se interseccionan las identidades entre clase, raza y política.

PALABRAS CLAVE: identidades, clasificaciones, Argentina, raza, clase

Race and Class in the Origins of Peronism: Argentina, 1945

In the context of discussions about race and class identifications, this article analyzes two terms used pejoratively to designate Peron followers: "descamisados"-shirtless-, and "cabecitas negras"-black heads-. The mobilization of October 17th, 1945 was the largest labor protest in South America until then. It opened a debate on who were the protagonists. Antiperonist identify them in terms of class and race. Peronist reactions to them were very different: on the case of "descamisados," Peron inverted its meaning; on the case of "cabecitas negras" he was silent. This essay contributes to understand identity intersectionalities between class, race and politics.

KEYWORD: identities, classifications, Argentina, race, class

ALEJANDRO GRIMSON

Consejo Nacional de Investigaciones Científicas y Técnicas, Universidad Nacional de San Martín, San Martín, Provincia de Buenos Aires, Argentina alegrimson@gmail.com 
ste artículo busca mostrar la vigencia de las categorías de clase y raza para el análisis de usos identitarios situados, pero no para consideraciones teleológicas acerca de alguna conciencia "necesaria". En ese sentido, expone articulaciones históricas complejas por medio del análisis de los orígenes del peronismo en Argentina. Para comprender el tipo de análisis de las categorías de identidad que se desarrollará, conviene distinguirlo tanto de las teorías sustancialistas como de las posmodernas de la identidad (Brubaker y Cooper, 2000). Ni los grupos tienen una identidad, ni tomarán conciencia, pero tampoco las identificaciones son una mera cuestión de elección libre o manipulación.

En este trabajo, los procesos de identificación y sus categorías se analizan en términos relacionales, vinculados a la construcción de fronteras (Barth, 1976) y en situaciones de fricción (Cardoso de Oliveira, 1996; 1992). Las dimensiones significantes del conflicto social pueden expresarse en términos identitarios (Grimson, 2011). Los usos de categorías de clase y raza en la Argentina de 1945, así como las respuestas diferenciales, no permiten concebir de modo situado la persistencia de las desigualdades (Tilly, 2000). Este trabajo mostrará que un par de categorías vinculado a la clase — en términos de los actores "encamisado"|“descamisado"no ha persistido, mientras otro — "blanco"/“cabecita negra" — ha sido persistente.

El surgimiento del peronismo implicó la emergencia de una serie de categorías sociales de clasificación y significados. Cada una planteaba su respectiva intersección entre clase, raza y política. En este artículo se analizan dos términos utilizados para designar de manera peyorativa a los seguidores de Perón: "descamisados" y "cabecitas negras". En las diferencias de significado de ambos y en las reacciones del peronismo ante ellos se encuentra la articulación específica entre identificaciones de clase y de raza que se produjeron a partir de 1945.

El 17 de octubre de 1945, los obreros que trabajaban y residían en los suburbios ingresaron a Buenos Aires. Las columnas se dirigieron a la Plaza de Mayo para reclamar la liberación del coronel Perón, detenido cuatro días antes, después de renunciar a sus cargos en el gobierno. En especial como secretario de Trabajo y Previsión, había impulsado una gran cantidad de beneficios y derechos para los trabajadores.

Los obreros que desfilaban por las calles de una ciudad orgullosa de su europeidad eran un hecho inédito. ¿Cómo nombrarlos? ¿Qué categorías sociales los 
designaban? Eran "las masas". ¿Y quiénes son "las masas"? ¿Qué rostros tienen, cómo se visten, cómo hablan, cómo cantan? ¿Cómo son nominadas y cómo se nominan a sí mismas? Ese día, que culminó cuando Perón habló desde la Casa Rosada después de las 11 de la noche, abrió un periodo de disputa social y política acerca de quiénes eran los que habían ocupado la plaza y la ciudad. Había hecho eclosión un sistema clasificatorio y emergían nuevas categorías de identificación. Los actores sociales y políticos buscaron establecer un significado acerca de los protagonistas. De esa definición podría deducirse el significado de los hechos. Esas formas de categorización y significación anudaban desigualdades, formas de pertenencia, presunciones sobre los derechos y la ciudadanía. Así, surgieron formas de identificación que procuraron dar pie a un cierre y una estabilidad clasificatoria.

Se analizaron las fuentes primarias disponibles sobre 1945, incluyendo todos los periódicos, ${ }^{1}$ fotografías (Amaral y Botalla, 2010), entrevistas con protagonistas editadas y material de archivo. Se buscaron las maneras de nominar a quienes apoyaban a Perón, se estudiaron las categorías de autoidentificación y heteroidentificación, así como los significados disputados sobre categorías compartidas.

\section{El 17 de octubre}

Durante todo el día, empleados, obreros, trabajadores, la mayoría de ellos jóvenes, con presencia clara de mujeres, ocuparon las calles de la ciudad de Buenos Aires y la Plaza de Mayo. ¿Quiénes eran? Si bien Perón comenzó su discurso de esa noche con el término "trabajadores", comenzaremos por considerar las reacciones de la oposición.

Los habitantes de la ciudad, una sociedad establecida, orgullosa de ser cosmopolita, blanca y europea, percibieron con la extrañeza de lo desconocido la presencia de esos grupos y columnas en las calles.
Estupor, vergüenza, desprecio, indignación, compasión, desinterés, tristeza y temor son algunas de las emociones que manifestaron. Esas presencias eran, por decir lo menos, una ruptura total de la cotidianidad. Se trataba de algo insólito. La multitud real chocó con la imaginación instituida. Con esa "invasión” se planteó la pregunta de quiénes eran y cómo nombrarlos. La disputa política tenía una dimensión crucial en la lucha por los modos de nominación de los protagonistas.

En un libro publicado ese mismo año, Florencio Escardó había dicho que Buenos Aires era "una ciudad de raza blanca y de habla española". Afirmaba que no había negros, aindiados ni mulatos. Es "mucho más blanca (blanquísima) que Nueva York” (1945: 18). Por eso mismo, diría el historiador Félix Luna un cuarto de siglo después, "lo más singular del 17 de octubre fue la violenta y desnuda presentación de una nueva realidad humana [...]. La ciudad los vio con la misma aprensión con que vería a los marcianos" (1971: 273). ${ }^{3}$ Martínez Estrada, uno de los ensayistas más famosos del país, escribió en 1956:

El 17 de octubre Perón volcó a las calles céntricas de Buenos Aires un sedimento social que nadie habría reconocido. Parecía una invasión de gentes de otro país, hablando otro idioma, vistiendo trajes exóticos, y sin embargo era parte del pueblo argentino [...]. Sentimos escalofríos viéndolos desfilar en una verdadera horda silenciosa con carteles que amenazaban con tomarse una revancha terrible (2005: 55-56).

1 La Nación, La Época, Crítica, Noticias Gráficas, La Vanguardia, Orientación y La Capital (Rosario).

2 Para conocer relatos y análisis de los sucesos del 17 de octubre, véanse Gambini (1971); Torre (1995); Senén y Lerman (2005).

3 El subrayado en todas las citas es mío. 


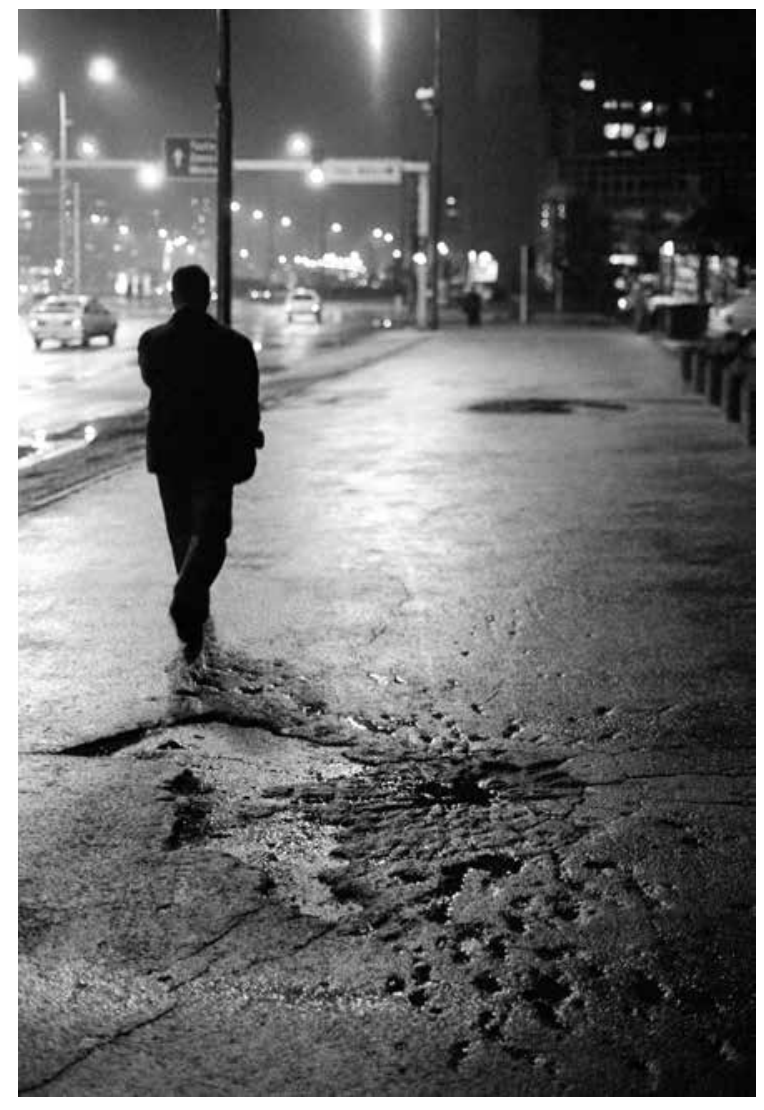

RICARDO RAMIREZ ARRIOLA $/ 360^{\circ}$ - Sarajevo después de la guerra, Bosnia y Herzegovina, 2000.

¿Cómo denominar a los marcianos o a los extranjeros? Ante un fenómeno inédito, imposible de imaginar hasta ese momento, cuyos protagonistas no habían sido figurados por la sociedad establecida, ${ }^{4}$ se inauguró un periodo de inestabilidad o crisis categorial (Grimson, 2015) en el que oradores y articulistas buscaron palabras para designar lo ocurrido.

En diarios, revistas y discursos abundan términos como hordas, turbas, masas, lumpenproletariat, malevaje, malón, chusma, obreros, descamisados, negros, alpargatas, tribu. ${ }^{5}$ Muchas de ellas tenían una larga tradición, como obrero, chusma, turba, masa, pero otras son inventadas en relación con el proceso de confrontación, que se agudiza en 1945.
Los términos utilizados por los antiperonistas intentan mostrar con distintos énfasis que esa presencia es lo contrario al pueblo de los "auténticos obreros" o trabajadores. Son términos despreciativos, que combinan las denuncias de los "adictos" y otras referencias explícitamente políticas, con nociones clasistas y racistas. La categoría "cabecitas negras" nunca se escribe como forma denigratoria, exhibe toda su potencia en la oralidad. Dos características serán utilizadas para fabricar esas alteridades: la vestimenta y el color de piel. A continuación, nos concentraremos en dos términos que surgieron en aquellos años: descamisados y cabecitas negras.

\section{Descamisados}

El término se empleó después del 17 de octubre para nominar a sus protagonistas. Fue utilizado en $\mathrm{La}$ Vanguardia, periódico del Partido Socialista, en un artículo titulado "El tango de la candidatura" (23 de octubre de 1945: 8). En un tono irónico, de burla de los sucesos, dejaba caer la alusión a "murgas carnavalescas con sus muchachones descamisados y elementos del hampa". La semana siguiente el término aparecía en otro artículo, que explicaba la lectura bélica: "Ha llegado la hora de combatir" (La Vanguardia, 30 de octubre de 1945: 3). ¿Era para tanto? Sí, porque cuando la "muchedumbre amorfa

"Sociedad establecida" alude a la sociedad que se percibía como blanca y europea en aquella época en Buenos Aires, en el sentido de Elias y Scotson (2000).

5 Cabe resaltar la importancia que tuvieron el periódico socialista La Vanguardia y el órgano comunista Orientación en las semanas inmediatamente posteriores al acontecimiento. La inestabilidad categorial puede percibirse con detalle al contrastar la crónica del diario tradicional La Nación del 18 de octubre, con su editorial del día 21. En sólo unos días deja de referirse a "los obreros" y comienza a editorializar el suceso a partir de la matriz de civilización y barbarie, ya analizada por Svampa (2006). 
y descamisada gritaba en las calles 'Alpargatas sí, libros no', comprendimos que su triunfo, si llegase, habría de terminar con la civilización para restaurar la barbarie" (La Vanguardia, 30 de octubre de 1945: 3). El autor alude a una de las consignas de los manifestantes que más escozor produjo en la sociedad establecida, que encontraba en el rechazo a los libros la confirmación cristalina de la barbarie. Los trabajadores, sin embargo, no aludían al libro como material de lectura, sino al símbolo político y clasista de quienes los denigraban y atacaban a Perón. La historia de estas confrontaciones está repleta de estas matrices de interpretación discordantes que durante largo tiempo parecieron disfrutar su mutua inconmensurabilidad.

El significado del término descamisado es llamativo. El Diccionario de la lengua española (RAE, 2017) señala un significado coloquial, "sin camisa", y otro despectivo, "muy pobre, desharrapado". En 1945, en Argentina, tuvo significados distintos. Varios cronistas se escandalizaron porque los manifestantes marchaban en "mangas de camisa" (La Capital, 19 de octubre de 1945), es decir, sin saco. Se sabe y se aprecia en fotos que varios manifestantes llevaban saco. Sin embargo, eran más sin saco y con camisa, lo cual era escandaloso en el centro de la ciudad.

Buenos Aires era muy formal en el vestir en 1945. En el centro se usaba saco y corbata, trajes de colores oscuros y por lo general sombrero, pero nunca se dejaba la cabeza descubierta. "Los porteños, con su típica frivolidad y narcisismo, habían llegado a pensar que todo el país era así", dice como testigo el sociólogo José Miguens (citado en Chávez, 1996: 61). Nadie había visto a los obreros industriales que se concentraban en los alrededores de la capital. "Y de pronto comenzaban a aparecer desde todas las calles, muertos de cansancio [...], hombres y chicos en alpargatas, con la cabeza descubierta, con pantalones muchos de ellos desflecados y camisas abiertas por el calor; mujeres con chicos en brazos con $c a-$ misolas largas [...], se iban concentrando en la Plaza y llenándola" (1996: 62). Es decir, tenían camisas o camisolas, pero el contraste con la formalidad de la ciudad los convertía en "un espectáculo asombroso" (1996: 62).

Aunque muchas de las fotos del 17 de octubre muestran concurrentes con saco, con camisa y en camiseta, incluso en la más famosa, con los hombres que descansan sus pies en el agua de la fuente de Plaza de Mayo, el término "descamisado" se torna posible porque remarca la diferencia, la generaliza y homogeneíza a los participantes de la movilización como pobres, que ignoran el estilo urbano y no siguen las reglas de etiqueta. Es una sinécdoque similar a la que se produce con "cabecitas negras": una parte despreciada y más fácilmente estigmatizable para la sociedad establecida, según sus criterios jerárquicos, se pretende que represente al todo heterogéneo. La cuestión de la vestimenta ocupó un lugar central para inferir la calidad de las personas que desfilaban.

Hay anécdotas de trabajadores que ese día pidieron sacos prestados para ir al centro (Chávez, 1996; Michelini, 1994). Eso indica varias cosas. Primero, que no tenían planeado ir cuando salieron de su casa, es decir, la inmensa mayoría se enteró de la convocatoria en la puerta de su trabajo, donde estaban los delegados o líderes. Por eso pedían los sacos esa mañana. Además, los pedían porque querían ir al centro vestidos de manera adecuada. Seguramente, la mayoría de los trabajadores no tenía un saco, y la sociedad jerárquica no tuvo clemencia. A los ojos porteños estaban mal vestidos y eso planteaba una fuerte cuestión estética.

El mismo 17 por la tarde, el diario Crítica minimizó lo que estaba ocurriendo al describirlos con la frase "grupos aislados que no representan al auténtico proletariado argentino"; y agregaba que "aparte de otros pequeños desmanes, sólo cometieron atentados contra el buen gusto y contra la estética ciudadana afeada por su presencia en nuestras calles" (Crítica, 17 de octubre de 1945). Félix Luna 
polemiza con los críticos de los manifestantes: "Claro está que se dieron escenas desagradables desde el punto de vista estético: no era un espectáculo grato el que ofrecían esas mujeres desgreñadas, esos muchachotes de astrosa pinta, esa gente sucia, sudada y vociferante" (1971: 311). Con ironía, da testimonio de una matriz de lectura de los cuerpos contundente.

Las ropas y sus implicaciones estéticas demostraban que no eran personas con las mismas cualidades intelectuales de la sociedad establecida. Era una "indigencia más mental que física”, afirmó el dirigente del Partido Socialista Américo Ghioldi ( $\mathrm{La}$ Vanguardia, 23 de octubre de 45). Esa identificación instituía la irracionalidad de sus acciones.

\section{La inversión}

"Descamisado" era un término polisémico: significaba simplemente "pobre", "mal vestido" o "sin saco". Esta ambigüedad habilita una productividad política que se percibe en el acto en el cual Perón invierte el significado del término. Perón asoció a los "descamisados" con los sans-culottes franceses, una imagen poderosa opuesta a aquello que el antiperonismo buscaba demostrar. El 14 de diciembre de 1945, en plena campaña electoral, Perón dijo en su discurso:

\footnotetext{
Desfilaremos por nuestras calles tranquilos, entusiastas de nuestra causa, sin calificar a nadie de chusma ni de descamisados, para contrapesar a ellos que han lanzado el calificativo despectivo. ¡Tendremos el corazón bien puesto debajo de una camisa, que es mejor que tenerlo mal debajo de una chaqueta! (citado en Luna, 1971: 412).
}

Cuando terminó su discurso, en medio de los aplausos, Perón tomó con la mano el asta de una bandera que portaba una camisa. Cuando agitó el estandarte, la multitud celebró. Perón denunciaba el "calificativo despectivo", lo revindicaba positivamente y lo convertía en un símbolo del peronismo, que respondía a la pregunta acerca de quiénes eran.

A partir de allí se instituyó un ritual en los actos peronistas con otros dirigentes. En un momento determinado de su discurso, se quitaban el saco y quedaban en mangas de camisa, lo que despertaba el fervor de los asistentes. Dos años después, el 17 de octubre de 1947, "Perón, como era costumbre, inició su discurso con la chaqueta puesta, pero ante la insistencia de la gente, accedió a quitársela (lo que haría sistemáticamente en los años sucesivos) para señalar su condición de 'primer descamisado"' (Plotkin, 2007: 198).

Las imágenes de los trabajadores que circularon en la propaganda gráfica entre 1946 y 1955 presentaron tres versiones en sus atributos: descamisado, en particular para la conmemoración del 17 de octubre; obrero industrial, y peón rural (Gené, 2005 : 12). En las imágenes oficiales, los trabajadores en general están con camisas o camisolas, muchas veces arremangados o con las camisas abiertas. Después, "descamisado" devino un término mucho más amplio. Perón pidió:

Grabar la historia del descamisado desde la Colonia, desde el indio encomendero que fue el primer descamisado, hasta la etapa del 17 de octubre... Debe tomarse la época de la colonización, donde tomemos al descamisado trabajando la tierra. Luego tomarlo en la Independencia, con su caballo, luchando por ella. Ahí tenemos al "deshilachado" de Güemes (Presidencia de la Nación, 1952: 70).

Eva Perón explicó:

Para mí los hombres y mujeres de trabajo son siempre, y ante todo, descamisados (1951: 115).

Descamisados fueron todos los que estuvieron en la Plaza de Mayo el 17 de octubre de 1945 [...]. Aun si hubo allí alguien que no lo fuese, 
materialmente hablando, un descamisado, ése se ganó el título por haber sentido y sufrido aquella noche con todos los auténticos descamisados; y para mí ése fue y será siempre un descamisado auténtico (1951: 116-117).

También son descamisados quienes hoy o mañana harían lo mismo que "los primeros descamisados", porque "es el que se siente pueblo [...] aunque no vista como pueblo, que esto es lo accidental” (Perón, 1951: 117). Como dice Gené, "el descamisado ocupó la más alta jerarquía en el panteón peronista. Fue, en la memoria colectiva, símbolo del origen y del triunfo, el sujeto como extensión de un pueblo que se incorpora a la historia nacional" (2005: 83).

Sin embargo, "descamisados" no habría siempre. El propio Perón consideraba que había logrado terminar con esa situación. En 1952, dijo ante la Asamblea Legislativa que gracias a los logros sociales de su gobierno "los que eran 'descamisados' en 1945 ya no son 'descamisados', aunque les guste y nos guste llamarlos así como un homenaje al 'descamisado' que todos los peronistas llevamos en el corazón” (citado en Ciria, 1983: 310).

En 1947 se planificó la construcción de un monumento al descamisado. Hasta ese límite se imaginó desplazar la inversión realizada con efectividad por Perón en 1945. Es evidente que hubo algo que no convenció a Perón, porque su gobierno concretó cosas bastantes más complejas que monumentos.

Es razonable preguntarse por qué la inversión de significado se produjo sobre el término "descamisado" y no en otras categorías. Al lado de descamisado, desharrapado parece ser muy baja, de ropas rotas, de mayor pobreza. Descamisado, como oposición al traje, con una camisa junto a la bandera argentina, era un complemento más adecuado para trabajadores. Es claramente una respuesta a una acusación. El propio término implica una negación y una oposición con los "encamisados”. En aquel momento inicial guardaba una fuerte ironía que se fue diluyendo en la solemnidad de los años posteriores.

Perón y el peronismo encontraron en ese término un modo de incorporar a la definición de "quiénes eran" un significante más recargado que "trabajadores", ya que implicaba en su propia enunciación el desprecio de la "gente decente". Además, quitarse el saco en público implicaba otras cuestiones: que no se carecía de saco, que se llegaba con él y que el ritual identitario se producía en el acto voluntario de quitárselo, para quedar en camisa o incluso con la camisa arremangada. Era el rechazo a las formas tradicionales de la "decencia" establecida, como un acto voluntario de aquellos que no por eso dejarían de usar saco.

Se trata de la apropiación de un significante, operación muy distinta de la realizada para afirmar de manera positiva black is beautiful, o la asunción indígena de los movimientos indigenistas. El peronismo, al menos en su vertiente oficial y principal, nunca actuó de ese modo. En esa ambigüedad, se jugaba una dinámica de las identidades que permite dialogar con los estudios acerca de si el peronismo constituyó una fuerte "cultura obrera" o "popular" completamente alternativa a la visión hegemónica, un modelo cultural diferente, o si más bien implicó un modo más amplio de acceso a ciertos bienes o símbolos compartidos. Ésta es una cuestión central que puede rastrearse en los usos del criollismo estudiados por Adamovsky (2014), en los estudios sobre el melodrama y la industria cultural desarrollados por Karush (2010), y más en general, por la nueva historia cultural del peronismo (Karush y Chamosa, 2010).

En torno a la pregunta de cuánto hubo de ruptura y de continuidad, este ensayo muestra que la inversión de sentido del término "descamisado" nunca se produjo con "cabecita negra”. Esto tuvo consecuencias graves, porque cuando una identificación denigratoria es apropiada por los denigrados tiene posibilidades de desaparecer como estigma. 
De hecho, mientras el término "descamisado" sólo permaneció como una categoría de autoidentificación, que implica en sí misma una denuncia de pobreza y de discriminación, el término "cabecita negra" mantuvo fuerte vigencia como forma de estigmatización y viró en ocasiones y según los momentos hacia "negro peronista", "negro villero", "negrada", "negro de alma”, entre otros.

\section{Cabecitas negras}

Buenos Aires es "una ciudad de raza blanca y de habla española [...]. Es la ciudad blanca de una América mestiza. En ella un negro es tan exótico como en Londres. Y un gaucho también" (Escardó, 1945: 17). Son las palabras satisfechas que escribió Florencio Escardó en su Geografía de Buenos Aires. Escardó era médico, tuvo una cátedra que hacía trabajo social y asistencial, fue decano de la Facultad de Medicina de la Universidad de Buenos Aires y vicerrector de la misma casa de estudios. Señalaba que la ciudad:

Es mucho más blanca (blanquísima) que Nueva York, que para conservarse blanca tiene que hacer racismo a piedra y lodo. Tampoco tiene aindiados ni mulatos. Sus hombres y mujeres no poseen todos el mismo color ni en la piel ni en el cabello, pero son blancos (1945: 18).

Esto es una "buena posibilidad eugénica" que coincide con que Buenos Aires sea "la sede los colonizadores y no de los colonizados" (Escardó, 1945: 18). Cuando en su "época de oro" la Editorial de la Universidad de Buenos Aires decidió reeditar el volumen, en 1966, las palabras anteriores permanecieron intactas. De esa matriz proviene la idea de "marcianos" que hemos citado:

Lo más singular del 17 de octubre fue la violenta y desnuda presentación de una nueva realidad humana [...]. Y eso es lo que resultó más chocante a esta Buenos Aires orgullosa de su rostro europeo: reconocer en esa hora desaforada que tenía el color de la tierra, una caricatura vergonzosa de su propia imagen (Luna, 1971: 273).

Se produce un contraste contundente entre el rostro europeo y el color de la tierra, que aparecía para la sociedad establecida como algo ajeno por completo a sí misma. Esa irrupción:

No provocó el rechazo que provoca una fracción política partidista frente a otra: fue un rechazo instintivo, visceral, por parte de quienes miraban desde las veredas el paso de las turbulentas columnas (Luna, 1971: 273).

Rostros morenos y pelos renegridos conformaban el rostro proteico de esa multitud pobremente vestida (1971: 275).

Luna narra de manera autobiográfica que en las reuniones con sus amigos, por lo general universitarios, ellos creían que en realidad no había peronistas. Cuando tenían oportunidad de salir con una chica, éstas siempre pertenecían a las filas de la oposición. En la descripción de su propia actitud como joven radical, el 17 de octubre de 1945 dice:

Los mirábamos desde la vereda, con un sentimiento parecido a la compasión. ¿De dónde salían? ¿Entonces existían? ¿Tantos? ¿Tan diferentes a nosotros? [...]. Ese día, cuando empezaron a estallar las voces y a desfilar las columnas de rostros anónimos color tierra, sentíamos vacilar algo que hasta entonces había sido inconmovible (1971: 321).

El carácter homogéneo, moreno o mestizo, de los manifestantes es irrefutable. Puede dudarse de la justeza de la descripción, pero no de cuán representativa sería la percepción de la diferencia de clase 


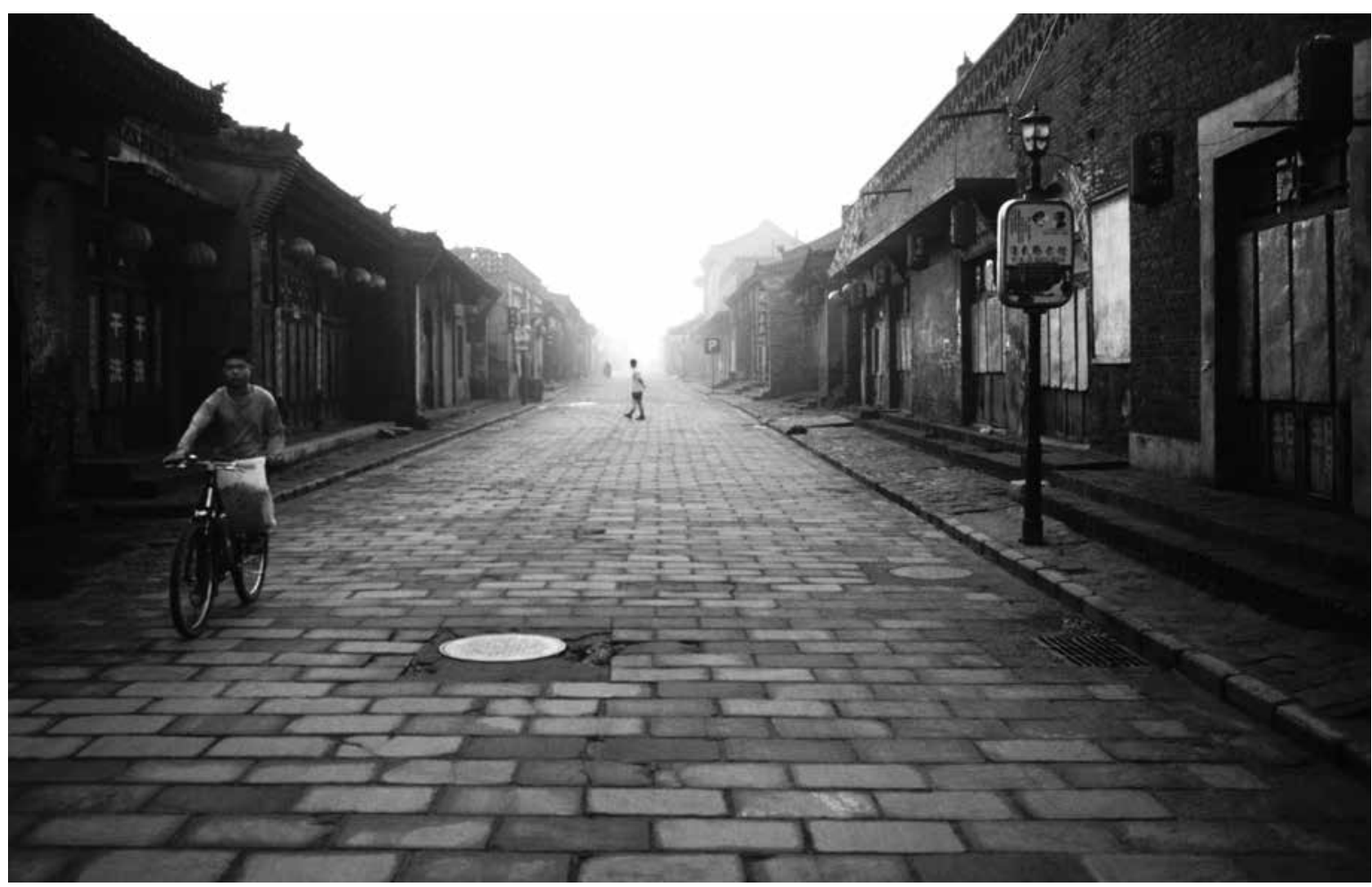

Ricardo Ramírez Arriola/360 Pingyao, provincia de Shanxi, China, 2007.

como diferencia racial. Luna no tiene connotaciones peyorativas para esa diferencia. Su intención consiste en mostrar cuán parcial era la visión que su grupo tenía de la sociedad Argentina, lo cual - aclaremos - no lo lleva a modificar su identidad política, sino a tratar de entender aquel momento de incomprensión.

Es necesario hacer una aclaración sobre el término "negro" en Argentina. "Negro" tiene distintos usos, en ciertos contextos es incluso un término de proximidad y afectividad. Para nombrar a algunas grandes figuras públicas se antepone la palabra "negro" como muestra de cercanía y cariño, por ejemplo, a Mercedes Sosa se le conocía como la "Negra" Sosa. En el ámbito familiar, en las clases populares y medias, es posible que las personas llamen a sus hijos o parejas de manera cariñosa como "negros": "che, negra".
El significado cariñoso o despectivo es muy claro para los hablantes de la lengua y depende del contexto. Aunque la variedad de significados del término "negro" plantea una complejidad adicional, para los hablantes no hay ninguna confusión. En 1945, el uso despectivo y racista en política tenía antecedentes, y no sólo en el siglo XIX, sino que la elite tradicional ya había aludido a "los negros radicales", en referencia a quienes apoyaban a Irigoyen (Cantón, citado en Fayt, 1967: 343). Ni una gota de cariño había allí: puro desprecio.

El estallido del imaginario blanco encontró diagnósticos y pronósticos en otro autor desde 1945. El médico Juan Emiliano Carulla veía con espanto "el resurgimiento de la raza de color" en el continente, proceso al que se refería como "América se negrea" (1951: 264), para decir "ennegrece". Ante las manifestaciones callejeras que había contemplado 
en Buenos Aires, "compuestas, en su gran mayoría, de mestizos y aun de indios" (Carulla, 1951: 264), su angustia aumentó, según describe, por "la revelación evidente de que Argentina también se negrea". No sólo es un ejemplo de racismo, sino también de la sinonimia argentina de "negro" con "indio" y "mestizo".

¿Quién es el "cabecita negra"? Es del interior —no de Buenos Aires-y tiene ascendencia indígena. Viene de las provincias supuestamente intocadas por la modernidad, de las zonas rurales. Queda enmarcado en las dicotomías argentinas de tradición y modernidad, civilización y barbarie, capital e interior, urbano y rural, culto e inculto (Svampa, 2006).

Las categorías de discriminación no siempre se prestan a definiciones simples y unívocas. Se supone que "cabecita negra" alude al color de pelo, por lo general al "pelo duro", y muchas veces a una piel oscura. "Piel oscura" es una fórmula ambigua: no significa "afro". La oscuridad de la piel puede no ser una cuestión cromática, sino más bien de jerarquía social. Supuestamente, el cabecita negra es en específico el obrero llegado desde las provincias, de rasgos aindiados, con el cabello hirsuto y renegrido.

De este modo, se construye un "otro" negro —en el sentido argentino de "no blanco"- que, como es evidente, resulta crucial para definir la propia identidad blanca, europeísta, urbana, educada y antiperonista. La presencia de los "cabecitas negras" en la capital hizo añicos el mito de la homogeneidad y singularidad argentina, elaborado con cuidado, al tiempo que produjo como reacción una visión racial de una clase media blanca durante la época peronista (Adamovsky, 2010; Garguin, 2007). La clase media y un número de intelectuales posteriores denostaron y racializaron a los militantes peronistas (Winston, 1983: 312; Milanesio, 2010).

Esto resolvía varios problemas al mismo tiempo. Acusaba de indignos a quienes apoyaban a Perón, los homogeneizaba como no blancos, y por último, pero no menos importante, afirmaba la identidad blanca de los estigmatizadores.

"Cabecitas" nace como la racialización de los seguidores de Perón, que sin embargo no tenían un rasgo racial definido. En su vida posterior, cuando se vincula con el término "negro", mostrará una capacidad amplia en relación con los sujetos a los que se refiere. ¿Por qué? Porque son términos raciales que aluden a personas "inferiores", con "menos educación”, "poca cultura", que "no saben comportarse", "peronistas". En la actualidad, el aspecto racista del término "negro" en Argentina se usa cuando la intención es inferiorizar por razones sociales, políticas, culturales, urbanas o cualquier otra a personas de cualquier color de piel (Frigerio, 2006; Adamovsky, 2012; Grimson, 2012).

¿Eran en verdad heterogéneos los seguidores de Perón y la sociedad establecida vio más "cabecitas" de los que había en la realidad? O más bien, ¿todos los peronistas eran “cabecitas"? En las imágenes del 17 de octubre de 1945, de las movilizaciones posteriores, de dirigentes sindicales y fundadores del Partido Laborista, y en general en todas las imágenes de los peronistas, vemos personas de varios colores de piel y rasgos fenotípicos. La heterogeneidad social, cultural y fenotípica fue anulada por los antiperonistas.

Más adelante, intelectuales peronistas construyeron un relato místico y épico con la idea de una nueva clase obrera auténticamente argentina, en oposición a los trabajadores llegados de Europa. En algunas interpretaciones muy cercanas al peronismo, esta clase obrera tenía marcas de la patria, de la nación, de los que pelearon por la independencia, del folclor, de la cultura nacional que se opondría al cosmopolitismo europeizante de Buenos Aires. Los intentos de "inversión" del término, como los de Ramos (1957) y Belloni (1962), son posteriores a 1955. Jamás provendrían de Perón ni de los principales dirigentes peronistas. 


\section{Pensar en los "cabecitas negras"}

Durante los diez años del primer peronismo y durante los 15 posteriores, no hubo un solo análisis académico que considerara la cuestión de los "cabecitas negras". A pesar del crecimiento de las ciencias sociales, la herida que mostraba el racismo argentino quedaría relegada. En 1961, Germán Rozenmacher publicó un cuento titulado Cabecita negra, que narraba relaciones racistas en Buenos Aires, al mismo tiempo que postulaba una metáfora más amplia sobre las clases medias. En 1966, en las páginas finales de El medio pelo en la sociedad argentina, Arturo Jauretche (2015) introdujo por primera vez el problema del racismo argentino y su negación. El individuo o grupo de "medio pelo" es aquel que trata de aparentar un estatus superior al que en realidad posee. Desde una posición de crítica del sentido común, Jauretche hablaba de la configuración económico-social e imaginaria de las aspiraciones de la distinción que constituye todo un estilo de posicionamiento ante la sociedad. Analizaba el dispositivo de jerarquización étnica y racial que se remontaba a Sarmiento y que mostró su vigencia en el surgimiento del peronismo (2015: 306 y ss.).

Dos estudios muy diferentes, con una relación variable con lo académico, nos acercan a los significados sociales que este término tenía para las clases alta y media de Buenos Aires. El primero es un estudio sociológico de De Imaz (1965), en el que aplicó una encuesta a miembros de la clase alta de Buenos Aires a finales de la década de 1950, después de la caída de Perón. Entre 1958 y 1959, De Imaz pregunta con agudeza: “A veces la gente habla de 'negros' o de 'cabecitas negras'. ¿Considera usted que esos términos son simplemente despectivos o que reflejan realmente a un grupo social?". Un proporción de 55\% de los encuestados afirmó que "refleja una realidad social", mientras 36\% dijo que era un término despectivo. Después preguntó: “¿Cree usted que dichos titulados 'negros' o 'cabecitas negras' también podrán con el tiempo ascender en la escala social, o mejor, que ascenderán?”. La respuesta de 49\% de los encuestados fue que no ascenderían y 42\% dijo que “ascenderían o podrían ascender” (1965: 53).

De Imaz hace una lista de motivos por los cuales, para sus entrevistados, ascenderán o podrán ascender: "porque poco a poco se educan y adquieren cultura", "porque debe haber algunos inteligentes", "por la acción del tiempo", "porque el mestizaje no es valla infranqueable", "siempre que tengan condiciones", "porque tienen aptitudes para lograrlo", “individualmente, en grupo no" (1965: 54). Motivos por lo general imprecisos y que en todo caso resultan reticentes respecto a la afirmación de que ascenderán: ni muchos, ni juntos, ni ahora; dependerá de varias condiciones.

Quienes dicen que no ascenderán argumentan: "por su falta de educación y cultura", "porque les faltan aspiraciones", "por causas raciales", "dado el medio negativo en el que viven”. También hay encuestados que responden que por "falta de principios”, "por ser haraganes o ineptos”, "porque no les interesa mejorar", "son tarados”, "carecen de capacidad y voluntad", "les falta moral” (1965: 55).

Con agudeza, De Imaz manifiesta sus dudas acerca "de que estas respuestas puedan interpretarse exclusivas del grupo social" encuestado. Sugiere que posiblemente también incluya a sectores medios (1965: 53-55). En la cuidadosa formulación de sus preguntas, De Imaz utiliza como sinónimos "negros" o "cabecitas negras".

El otro estudio es el análisis antropológico realizado por Ratier (1971), el cual, por primera vez, toma como objeto de análisis al "cabecita negra". Durante un cuarto de siglo, no encontraríamos nuevos trabajos sobre el racismo como dimensión central de la vida política en Argentina. A partir de información de su propio trabajo de campo en zonas populares, pero también de sus vivencias, Ratier 
combina la denuncia con un análisis de los significados del término. ${ }^{6}$

Se trata de un texto pionero en el análisis del racismo argentino, de los términos "cabecita" y "negro", de las relaciones entre clase y raza, o de la noción de "blanquitud" (Ratier, 1971: 9). Ratier confronta el imaginario de que "la Argentina no es un país racista" con las prácticas de exclusión de los no blancos (1971: 12). Enfatizaba "el matiz político que puso sal en el enfrentamiento cuasiracista de porteños y provincianos: ser 'negro' era ser peronista, y viceversa. Y los negros pisaban fuerte” (1971: 13). "En el choque entre porteños y 'cabecitas", aparece "el racismo argentino" (1971: 15). ¿Racista o cuasi racista? Ratier entiende que es más "un racismo por omisión que por afirmación" (1971: 17), porque se piensa más de lo que se dice que las "razas" europeas son superiores. Pero "el racismo forma parte principal del bagaje ideológico con que se organizó el país después de Caseros" (1971: 18). En 1945, “todas las armas son buenas en el enfrentamiento, incluido el prejuicio racial. Son 'negros ensoberbecidos', "cabecitas negras"' (1971: 32). Al igual que en De Imaz (1965), aquí "negros” y “cabecitas negras" son sinónimos.

Al mismo tiempo, Ratier desbiologiza el racismo en el sentido de que percibe un enfrentamiento político y social que tiene un condimento racial. Por eso insiste en que entre quien apoyaba a Perón no sólo había "mestizos", sino también rubios y gringos (1971: 33). Reitera que en la celebraciones que se hicieron durante la década peronista del $1 \mathrm{de}$ mayo y del 17 de octubre en la Plaza de Mayo "no había sólo 'cabecitas'. Pero no importa: la denominación social los englobaba" (1971: 38). Es decir, se designaba "cabecita negra" a quien apoyaba a Perón, aunque no fuera mestizo ni provinciano. Es decir, si eran "adictos" a Perón eran vistos como negros, es decir, la identificación política estaba racializada.
Como "cabecita negra" ha sido un término de la oralidad, sólo aparece en textos posteriores, poco citados, porque las grandes disciplinas y los autores reconocidos nunca se han ocupado de analizar estas cuestiones. El racismo argentino puede negarse porque tiende a verse como un elemento anecdótico y desagradable. No se comparte la tesis de que la sociedad argentina está constituida sobre las jerarquizaciones de ese racismo que no se estudia, salvo en las nuevas generaciones.

Por eso considero que es necesario destacar las reflexiones de Félix Luna en El 45, publicado en 1969 (Luna, 1971). Si bien Luna no presenta una teoría sobre el clasismo y el racismo, intenta describir las percepciones sobre esa nueva alteridad desde una mirada reflexiva que permite acercarse a los modos de mirar de la sociedad establecida: "esa gentecita morocha y humilde, leal y decidida que era igual a la que en las jornadas de octubre había salido a defender a su jefe [...] en febrero depositó silenciosa y disciplinadamente su voto" (Luna, 1971: 485). Hay una ironía en Luna, pero es acerca de las percepciones de su propio grupo, no sobre esa "gentecita", que explica de manera crítica el modo en que ellos mismos pensaban y categorizaban.

No es casual que estos textos sean de finales de la década de 1960 y principios de la de 1970. Esto se vinculaba al clima de época. El cambio puede verse en la publicación, en 1971, de la Nueva geografía de Buenos Aires, en la cual Escardó alude a las frases reproducidas en 1966 sobre la blanquedad de Buenos Aires. Cinco años después afirma que "nada de esto puede ser repetido con exactitud" (1971: 75). Sucede que "el interior, es decir, América, ha efectuado su marcha sobre Buenos Aires [...] casi inmediatamente después de la salida de la edición

Ratier consideró su texto como autobriográfico (Guber, 1999: 109). 
primera de mi libro", en 1945 (1971: 75). Sabemos que las migraciones internas habían comenzado una década antes. Lo que ocurrió después de su libro fue el 17 de octubre y el triunfo electoral de Perón. "La sangre mestiza hizo su irrupción en la urbe”, dice, y describe a todos los migrantes como portadores de ascendencia indígena. "La ciudad blanca los resistió apodándolos cabecitas negras" (1971: 76). Los sociólogos, fabula, "se apuraron a señalar el apodo como el índice indiscutible de una discriminación. Pero no hubo tal; en la mecánica del rechazo verbal se ocultó una rabiosidad política pero ni racial ni contrahumana; la propia palabra 'cabecita' contiene un diminutivo cariñoso” (1971: 76). ${ }^{7}$ Como se ve, el texto de De Imaz (1965), quien había trabajado varios años con Gino Germani, no había sido leído o tomado en serio.

En aquel clima, en su última contribución a los debates sobre el peronismo, Germani también se detuvo unas líneas en la noción de "cabecita negra". Citemos in extenso:

El componente "criollo" de la nueva clase trabajadora fue tan prominente que produjo la aparición de un estereotipo: el "cabecita negra", que a su vez fue sinónimo de peronista. Como todo estereotipo, poseía grandes distorsiones, pero también una fuerte base de realidad. Fue reconocido por todos: la clase obrera y la media, los peronistas y los antiperonistas, si bien con reacciones emocionales opuestas [...]. En un país tan llamativamente libre de prejuicios étnicos, este estereotipo adquirió peso emocional debido a su contenido político e ideológico, desapareciendo en el periodo posperonista (1973: 466).

Para Germani, la verificación de la "fuerte base de realidad" es que estaban todos de acuerdo en la existencia de una "nueva clase obrera", para algunos "auténtica", para otros "falsa". Es un procedimiento metodológico extraño para constatar la veracidad de un estereotipo. Es claro que nociones como "sentido común" todavía eran ajenas a nuestros principales sociólogos. Los consensos clasificatorios son eso, nunca prueba de veracidad. Pero además llama la atención que después de décadas de silencio sobre el término, sólo pueda hablarse de él en el mismo acto en que se declara su desaparición. Al comprender cuán constitutiva es esta visión de Argentina, puede pensarse en la vigencia de este silencio sobre el tema en gran parte de más de una generación. Declarada su desaparición en 1973, "negro" —utilizado por De Imaz (1965) como sinónimotiene hoy una enorme vitalidad estigmatizante que desmiente el imaginario de una Argentina "libre de prejuicios étnicos" (Grimson, 2012; 2014; Adamovsky, 2010; Frigerio, 2006; Segato, 2007; Caggiano, 2012). ${ }^{8}$

\section{Sin inversión}

Este gigantesco proceso de estigmatización instituyó en 1945 una frontera del desprecio para la masa de adherentes al peronismo. Racismo y clasismo se intersectaron en esta noción. En ese sentido, es probable que los antiperonistas hayan visto más “cabecitas negras”, más migrantes del interior, de los que había en esa masa social y culturalmente heterogénea.

7 En efecto, hay un pájaro llamado cabecita negra. La versión de que ése era el origen del término, difícil de verificar, tiene un componente lingüístico a su favor difícil de explicar: el artículo "el", masculino, es seguido por un sustantivo y un adjetivo femeninos.

Insisto en que a pesar de que el término "negro" puede ser utilizado en Argentina de modo afectivo y cercano en conversaciones entre amigos o familiares, y como categoría de proximidad o de adjetivación cariñosa de personajes célebres, su significado no se confunde de manera contextual con los usos discriminatorios y racistas. Mencionar al "Negro" Fontanarrosa no guarda continuidad con expresiones como "los negros que cortan rutas" o "los negros villeros". 
La oposición a Perón nunca hizo una crítica de ese racismo. Por su parte, sólo en los últimos años el mundo académico ha retomado el impulso bastante aislado de autores como Ratier. Se siguen escribiendo historias sobre el peronismo o sobre Argentina sin mencionar ni analizar ese racismo.

Por último, el peronismo nunca hizo una operación similar con "cabecita negra" a la que hizo con "descamisado". Esto es relevante para comprender cómo opera el peronismo ante los términos "cabecita negra" y "negro". No hubo una reivindicación positiva de una identidad negra, indígena o mestiza en el gran movimiento de masas ni en los grandes discursos. Nunca se diseñó el monumento al cabecita negra, nunca fue reivindicado por Evita o Perón.

No hubo un desafío abierto a la idea de una Argentina blanca. Los trabajadores querían incorporarse a la sociedad, incluso querían ser aceptados por quienes los denigraban. El poder del estigma "negro" fue gigantesco porque jamás se le enfrentó de manera abierta. Al calificar una identidad de clase y política, era claro que cualquier persona que saliera de ese mundo dejaría de ser "negro". Winston explica:

El término "descamisado" en lugar de cabecita negra describe con mayor precisión al trabajador peronista medio. Ambos términos fueron aplicados con sorna a los peronistas por sus enemigos, pero el régimen abrazó el concepto de descamisado mientras cabecita negra se convirtió prácticamente en una expresión prohibida bajo Perón. Esto por sí solo sugiere que el movimiento quiso apelar a toda la clase trabajadora y no a un segmento sobre otro (1983: 313) [la traducción es mía].

Si bien este argumento es interesante, hoy podemos ver las cosas de otro modo. No puede ser la razón principal: no todos los trabajadores eran literalmente descamisados, pues había desigualdades internas en cuanto al salario y la vestimenta de la clase trabajadora. No lo eran muchos ferroviarios o empleados de comercio, por mencionar algunos ejemplos. Es decir, "descamisado" es también una sinécdoque tanto en su origen estigmatizante como en su identificación.

"Descamisado" era un término que aludía a la etiqueta y por lo tanto podía ser respondido, disputado y apropiado. "Negro" y "cabecita negra" eran despectivos de manera tan poderosa que ni siquiera podían ser enunciados y denunciados en voz alta. Pudo haber sido rechazado de modo sistemático por el Estado como término racista desde 1946, sin haber intentado que fuera una identidad que éste abarcara. Pero para ello había que proponer un nuevo imaginario social, fenotípica y étnicamente heterogéneo.

¿Por qué no hubo una reivindicación de los cabecitas negras? El imaginario de la Argentina blanca y europea, que está en la base del mecanismo de estigmatización, producía en los trabajadores una cierta ambivalencia. "Negro" era el excluido, el no argentino, mientras que ellos querían ser ciudadanos argentinos y ser incluidos. La opción de atacar de manera directa el imaginario homogeneizante parecía arriesgada cuando Perón estaba planteando una promesa y un discurso de inclusión.

Sólo después, y para grupos acotados, se construyó un relato épico de los cabecitas negras que en 1945 no tenía ningún valor de reivindicación para los trabajadores.

A diferencia de sociedades como la del sur de Estados Unidos de mediados del siglo Xx, en la que la jerarquía y la exclusión se perpetúan sobre la base de un lenguaje explícitamente racial, la Argentina peronista no exige en el mismo sentido construir un movimiento de reivindicación positiva de una identidad denigrada. El Estado termina de manera superficial con esa denigración y avanza en lo jurídico en nuevos derechos. Por ello, el funcionamiento de las articulaciones entre identificaciones políticas, 


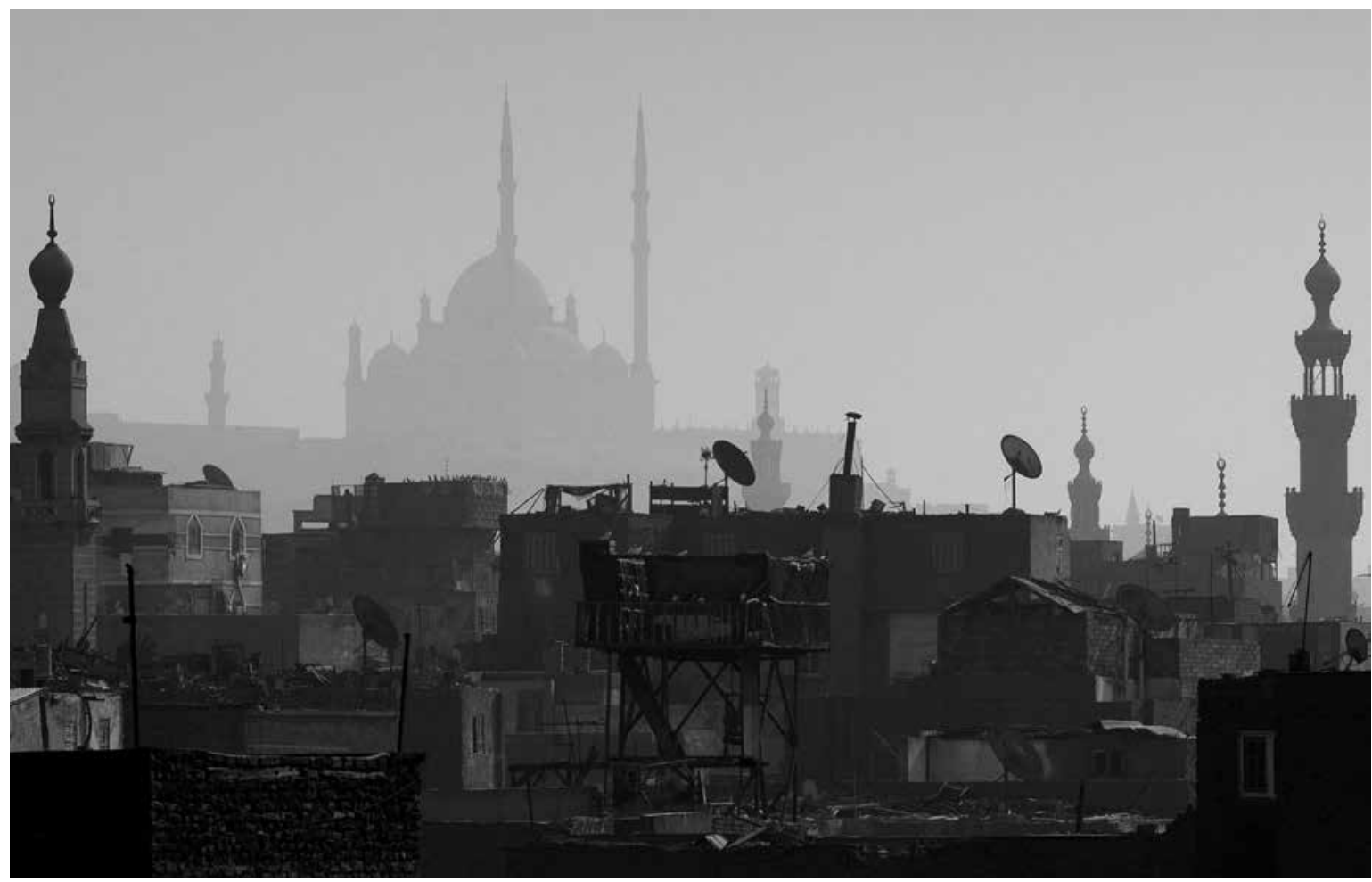

RicARdo RamíreZ ArRIOLA/360 En los techos de El Cairo islámico, Egipto, 2008.

de clase y raciales funciona de un modo muy distinto en Argentina, Brasil o Estados Unidos, como ya mostró Segato (2007). En Argentina, durante décadas, la identificación política ha sido un lenguaje con connotaciones de clase y raciales (Grimson, 2012).

Junto a ese lenguaje "moderno", obrero, sindical, peronista, habitarían otros procesos culturales, en los que aquellas historias se recrearían, sin desafiar de manera abierta los modos de imaginar la comunidad nacional.

\section{A modo de cierre}

La aparición de esas "masas" en la ciudad blanca el 17 de octubre y su persistencia en los años posteriores constituyó un trauma para la sociedad establecida. En 1945, con el nazismo derrotado, las ideas raciales eran las antípodas de las ideas democráticas. Entre las paradojas argentinas, se encuentra el hecho de que los actores políticos que se organizaban desde hacía años para luchar contra el nazismo eran los que tenían entre sus filas un racismo que nadie consideraba ni juzgaba como tal. Se trata de una sociedad jerárquica organizada en gran medida en función de rasgos fenotípicos, de criterios étnicos, territoriales y de fronteras de clase. Una sociedad que no reconocía esa dimensión constitutiva, que explica no sólo los tipos de trabajo a los que se podía acceder, sino también el tipo de exclusión social que se padecería.

El estereotipo tomó la parte por el todo, arrojó vituperios racistas sobre los sectores más débiles y postuló que ésas eran las bases sociales del 
peronismo. Las clasificaciones sociales del color en Argentina presentan la peculiaridad de que blanco y negro aluden, más que al color de piel, a la jerarquía de clase y étnica de las personas. Además, "negro" se asocia de manera directa a su identificación política.

Eso tiene una implicación crucial en la medida en que se trata al mismo tiempo de un sistema rígido y abierto. Abierto en el sentido de que cualquier persona, de manera individual, puede tener la ilusión de "blanquearse". Al no ser una concepción puramente fenotípica, los modos de hablar, vestir y comportarse han marcado diferencias relevantes. A la vez, es rígido porque esa frontera persiste en la actualidad. La estigmatización de "los negros" tiene plena vigencia. Esa solidez puede explicar por qué los sectores populares argentinos apelaron históricamente a discursos indirectos y no confrontativos (Adamovsky, 2014) con la definición de la nación blanca.

"Descamisado", a diferencia de "cabecita negra", podía escribirse para hacer burla de los seguidores de Perón. También era un término que podía invertirse. "Cabecita negra" sólo vivía en la oralidad, igual que "negro" en la actualidad. Nunca fue respondido ni invertido en el primer peronismo. Su reivindicación posterior quedó relegada a algunos autores, nunca a los dirigentes políticos más relevantes. El término "cabecita negra” sólo comenzó a ser analizado a mediados de los sesenta en unos cuantos textos. El análisis del racismo constitutivo de la sociedad argentina sólo ha sido retomado en los últimos años.

El caso de los usos de las identificaciones raciales y de clase en los orígenes del peronismo muestra dinámicas complejas entre procesos estructurales, de auto y heteroidentificación. Muestra que no se trata de biologías o conciencias esenciales, auténticas o necesarias, sino de articulación de intereses y de lenguajes culturales instituidos. Las disputas por los significados de los protagonistas del 17 de octubre y de los seguidores de Perón no revelan alguna homogeneidad oculta, más bien expresan la intensidad de los modos instituidos de percibir y clasificar, en las dinámicas contingentes, modos de estigmatización y de reivindicación identitaria, así como las consecuencias que las intervenciones de los agentes tienen en el proceso de configurar los imaginarios nacionales.

Así, la comparación entre estas dos categorías permite subrayar una cuestión conceptual relevante para comprender las particularidades del racismo argentino. Un énfasis teórico excesivo en la manipulación de identidades construidas de manera estratégica por actores que escogen con libertad sus categorías de afiliación no permitiría dilucidar la importancia de los procesos de sedimentación cultural. En ese sentido, para comprender la persistencia de las jerarquizaciones raciales y de la debilidad de su análisis académico, resulta crucial considerar "las circunstancias que no se han elegido", conformadas por un imaginario europeísta que tuvo impactos duraderos sobre la producción académica. La renovación de los estudios sobre el peronismo en relación con los procesos culturales y de identificación, en particular James (2010), la nueva historia cultural — varios autores editados por Karush y Chamosa (2010) - , la cuestión étnica y racial investigada por Adamovsky (2012; 2014), la reposición del carácter "disruptor" del peronismo como "hecho maldito" de Acha y Quiroga (2012), así como la renovación de los estudios antropológicos sobre Argentina — sería injusto proponer nombres propios que sinteticen un proceso más amplio-, habilita e impulsa el argumento de este trabajo, tanto respecto al lugar de las categorías racializadas como de sus visibilidades académicas. D 


\section{Bibliografía}

Acha, Omar y Nicolás Quiroga, 2012, El hecho maldito, Prohistoria, Rosario.

Adamovsky, Ezequiel, 2010, Historia de la clase media argentina, Planeta, Buenos Aires.

__ , 2012, "El color de la nación argentina. Conflictos y negociaciones por la definición de un ethnos nacional, de la crisis al Bicentenario", en Jahrbuch für Geschichte Lateinamerikas, vol. 49, núm. 1, pp. 343-364.

—_, 2014, "La cuarta función del criollismo y las luchas por la definición del origen y el color del ethnos argentino", en Boletín del Instituto de Historia Argentina y Americana "Dr. Emilio Ravignani”, núm. 41, pp. 50-92.

Amaral, Samuel y Horacio Botalla, 2010, Imágenes del peronismo, Editorial de la Universidad Nacional de Tres de Febrero, Buenos Aires. Barth, Frederick, 1976, “Introducción”, en Frederick Barth, Los grupos étnicos y sus fronteras, Fondo de Cultura Económica, México. Baschetti, Roberto (comp.), 2015, La plaza de Perón. Testimonios del 45, Capiangos, Buenos Aires. Belloni, Alberto, 1962, Peronismo y socialismo nacional, Coyoacán, Buenos Aires. Brubaker, Rogers y Frederick Cooper, 2000, "Beyond 'Identity”, en Theory and Society, vol. 29, núm. 1, pp. 1-47.

Caggiano, Sergio, 2012, El sentido común visual. Disputas en torno a género, "raza” y clase en imágenes de circulación pública, Miño y Dávila, Buenos Aires.

Cardoso de Oliveira, Roberto, 1996 [1964], O índio e o mundo dos brancos, Universidade Estadual de Campinas, São Paulo.

__, 1992 [1976], Etnicidad y estructura social, Centro de Investigaciones y Estudios Superiores en Antropología Social, México.

Carulla, Juan Emiliano, 1951, Al filo de medio sig/o, Llanura, Paraná.

Chávez, Fermín (comp.), 1996, La jornada del 17 de octubre por cuarenta y cinco autores, Corregidor, Buenos Aires.

Ciria, Alberto, 1983, Politica y cultura popular. La Argentina peronista 1946-1955, Ediciones de la Flor, Buenos Aires.

Elias, Norbert y John Scotson, 2000, Os establecidos e os outsiders, Jorge Zahar Editor, Río de Janeiro.

Escardó, Florencio, 1945, Geografía de Buenos Aires, Losada, Buenos Aires.

, 1966, Geografía de Buenos Aires, Losada, Buenos Aires.

,1971, Nueva Geografía de Buenos Aires, Américalee, Buenos Aires.

Fayt, Carlos (ed.), 1967, La naturaleza del peronismo, Viracocha, Buenos Aires.

Frigerio, Alejandro, 2006, “'Negros' y 'blancos' en Buenos Aires: repensando nuestras categorías raciales”, en Temas de Patrimonio Cultural, núm. 16, pp. 77-98.

Gambini, Hugo, 1971, El 17 de octubre, Centro Editor de América Latina, Buenos Aires.

Garguin, Enrique, 2007, "El tardío descubrimiento de la clase media en Argentina”, en Nuevo Topo, núm. 4, pp. 85-108.

Gené, Marcela, 2005, Un mundo feliz. Imágenes de los trabajadores en el primer peronismo, 1946-1955, Fondo de Cultura Económica, Buenos Aires.

Germani, Gino, 1973, "El surgimiento del peronismo: el rol de los obreros y de los migrantes internos", en Desarrollo Económico. Revista de Ciencias Sociales, vol. 13, núm. 51, pp. 435-488

Ghioldi, Américo, 1946, El socialismo en la evolución nacional, La Vanguardia, Buenos Aires.

Grimson, Alejandro, 2011, Los límites de la cultura, Siglo XXI Editores, Buenos Aires.

, 2012, Mitomanías argentinas, Siglo XXI Editores, Buenos Aires.

2014, “El sentido común de la discriminación”, en Ensambles, núm. 1, pp. 37-56.

, 2015, “Crisis y alteridad en la configuraciones culturales”, en Etnografías contemporáneas, vol. 1, núm. 1, pp. 140-160.

Guber, Rosana, 1999, “'El cabecita negra’ o las categorías de la investigación etnográfica en la Argentina”, en Revista de Investigaciones Folclóricas, vol. 14, pp. 108-120.

Imaz, José Luis de, 1965, La clase alta de Buenos Aires, Universidad de Buenos Aires, Buenos Aires.

James, Daniel, 2010, Resistencia e integración, Siglo XXI Editores, Buenos Aires.

Jauretche, Arturo, 2015 [1966], El medio pelo en la sociedad argentina, Corregidor, Buenos Aires.

Karush, Matthew, 2010, "Populism, Melodrama, and the Market", en Matthew Karush y Oscar Chamosa (eds.), The New Cultural History of Peronism, Duke University Press, Durham, pp. 21-51.

Karush, Matthew y Oscar Chamosa (eds.), 2010, The New Cultural History of Peronism, Duke University Press, Durham.

Luna, Félix, 1971, El 45: crónica de un año decisivo, Sudamericana, Buenos Aires. 
Martínez Estrada, Ezequiel, 2005, ¿Qué es esto?, Biblioteca Nacional/Colihue, Buenos Aires.

Michelini, Pedro, 1994, El 17 de octubre de 1945, Corregidor, Buenos Aires.

Milanesio, Natalie, 2010, "Peronists and Cabecitas: Stereotypes and Anxieties at the Peak of Social Change", en Matthew Karush y Oscar

Chamosa (eds.), The New Cultural History of Peronism, Duke University Press, Durham, pp. 53-84.

Perón, Eva, 1951, La razón de mi vida, Peuser, Buenos Aires.

Plotkin, Mariano Ben, 2007, El día que se inventó el peronismo, Sudamericana, Buenos Aires.

Presidencia de la Nación, 1952, Anécdotas, recuerdos, conversaciones, citas, relatos, ejemplos de Perón, Presidencia de la Nación-Subsecretaría de Informaciones, Buenos Aires.

Ramos, Jorge Abelardo, 1957, Revolución y contrarrevolución en Argentina: las masas en nuestra historia, Amerindia, Buenos Aires.

Ratier, Hugo, 1971, El cabecita negra, Centro Editor de América Latina, Buenos Aires.

Real Academia Española (RAE), 2017, “Descamisado”, en Diccionario de la lengua española. Disponible en línea: <http://dle.rae.es/?id=CbSVdFj>. Reygadas, Luis, 2008, La apropiación, Anthropos/Universidad Autónoma Metropolitana-Iztapalapa, México.

Rozenmacher, Germán, 1961, El cabecita negra, Capítulo, Buenos Aires.

Segato, Rita, 2007, La nación y sus otros, Prometeo, Buenos Aires.

Senén González, Santiago y Gabriel Lerman (comps.), 2005, El 17 de octubre de 1945, Lumiere, Buenos Aires.

Svampa, Maristella, 2006, El dilema argentino: civilización o barbarie, Taurus, Buenos Aires.

Tilly, Charles, 2000, La desigualdad persistente, Manantial, Buenos Aires.

Torre, Juan Carlos (comp.), 1995, El 17 de octubre de 1945, Ariel, Buenos Aires.

Winston, Colin, 1983, "Between Rosas and Sarmiento: Notes on Nationalism in Peronist Thought", en The Americas, vol. 39, núm. 3 , pp. 305-332.

\section{Hemerografía}

La Nación, septiembre a noviembre de 1945, Buenos Aires. La Época, septiembre a noviembre de 1945, Buenos Aires. Crítica, septiembre a noviembre de 1945, Buenos Aires. Noticias Gráficas, septiembre a noviembre de 1945, Buenos Aires. La Vanguardia, septiembre a noviembre de 1945, Buenos Aires. Orientación, septiembre a noviembre de 1945, Buenos Aires. La Capital, octubre de 1945, Rosario. 